\title{
Loss of CYLD might be associated with development of salivary gland tumors
}

\author{
MASAKATSU FUKUDA ${ }^{1}$, MIKI HIROI ${ }^{2}$, SEIJI SUZUKI ${ }^{1}$, YOSHIHIRO OHMORI $^{2}$ and HIDEAKI SAKASHITA $^{1}$ \\ ${ }^{1}$ Second Division of Oral and Maxillofacial Surgery, Department of Diagnostic and Therapeutic Sciences, \\ ${ }^{2}$ Division of Microbiology and Immunology, Department of Oral Biology and Tissue Engineering, \\ Meikai University School of Dentistry, 1-1 Keyakidai, Sakado, Saitama 350-0283, Japan
}

Received December 20, 2007; Accepted March 3, 2008

\begin{abstract}
Molecular studies of cylindromas, which arise from the eccrine or apocrine cells of the skin, have demonstrated frequent alterations at chromosome 16q12-13, recently found to house the cylindromatosis (CYLD) gene. CYLD, a tumor suppressor gene, has deubiquitinating enzyme activity and inhibits the activation of transcription factor $\mathrm{NF}-\kappa \mathrm{B}$. Loss of the deubiquitinating activity of CYLD is correlated with tumorigenesis. It has been reported that the expression of CYLD is observed in various organs. We demonstrated previously that human salivary gland tumor (SGT) cell line, HSG spontaneously expresses CYLD and also found that adenoid cystic carcinoma (ACC) arising from the hard palate was distinctly positive for CYLD, immunohistochemically. However, it is unclear whether loss of CYLD is associated with development of SGTs. This study examined CYLD function in SGT cells and attempted to clarify whether CYLD is associated with development of SGTs. The expression of CYLD and NF- $\mathrm{KB}$ mRNAs in HSG cells was increased by TNF- $\alpha$. Translocation of NF- $\kappa$ B protein from the cytoplasm to the nucleus in HSG cells peaked at $30 \mathrm{~min}$ after TNF- $\alpha$ stimulation, then decreased at $60 \mathrm{~min}$, whereas that of CYLD protein increased gradually in a timedependent manner. Luciferase reporter assay indicated that TNF- $\alpha$ induced a 5-fold increase of NF- $\kappa \mathrm{B}$-dependent transcription at $4 \mathrm{~h}$, which was further enhanced by knockdown of CYLD using RNA interference. Taken together, these data demonstrated that the levels of both CYLD and NF- $\mathrm{B}$ mRNAs accumulated in HSG cells during $24 \mathrm{~h}$ after TNF- $\alpha$ stimulation, although the NF- $\mathrm{BB}$ activity in the cells was at least negatively regulated by CYLD. Immunohistochemical
\end{abstract}

Correspondence to: Dr Masakatsu Fukuda, Second Division of Oral and Maxillofacial Surgery, Department of Diagnostic and Therapeutic Sciences, Meikai University School of Dentistry, 1-1 Keyakidai, Sakado, Saitama 350-0283, Japan

E-mail: fukudam@dent.meikai.ac.jp

Key words: cylindromatosis gene, nuclear factor- $\mathrm{\kappa}$, inhibitory $\kappa \mathrm{B} \alpha$, IкB kinase- $\alpha$, IкB kinase- $\beta$, adenoid cystic carcinomas examinations revealed that there are several correlations between the expression of CYLD and NF- $\mathrm{KB}$-related factors in 17 cases of ACC tissues. These findings suggest that loss of CYLD is associated with development of SGTs.

\section{Introduction}

Molecular studies of familial and sporadic cylindromas, that arise from the eccrine or apocrine cells of the skin $(1,2)$, have shown frequent alterations at chromosome 16q12-13, recently found to house the cylindromatosis (CYLD) gene (3-6). CYLD, a tumor suppressor gene, has deubiquitinating enzyme activity and inhibits the activation of transcription factor $\mathrm{NF}-\kappa \mathrm{B}(5,7-9)$, which has key roles in inflammation, immune responses, tumorigenesis and protection against apoptosis (10-12). In most cells, NF- $\kappa \mathrm{B}$ is kept inactive in the cytoplasm as a heterodimeric complex composed of p50 and p65 (RelA) subunits bound to the inhibitory protein, inhibitor of $\mathrm{\kappa B}$ $(\mathrm{I} \kappa \mathrm{B} \alpha)(13-15)$. Insight into the signaling mechanisms that lead to IкB $\alpha$ phosphorylation have identified a high-molecularweight protein complex known collectively as the IкB kinase (IKK) signalosome and including IKK $\alpha$, IKK $\beta$ and IKK $\gamma$ also known as NF- $\mathrm{BB}$ essential modulator (NEMO) $(16,17)$. IKK $\alpha$ and IKK $\beta$ have been identified as catalytic subunits, whereas IKK $\gamma$ is a regulatory subunit $(16,18)$. Generally, after stimulation by various reagents, IкB $\alpha$ is phosphorylated at serine residues 32 and 36 by IKK $\alpha$ and IKKß, together with the scaffold protein NEMO/IKK $\gamma(7-9,19)$. Serine phosphorylation results in polyubiquitination of $\mathrm{I} \kappa \mathrm{B}$ and its subsequent degradation by the proteasome, allowing NF- $\mathrm{B}$ to translocate to the nucleus and activate its target gene $(11,19,20)$. At this point, CYLD binds to NEMO/IKK $\gamma$ and appears to regulate its activity through deubiquitination of TRAF2 $(8,9)$. Therefore, loss of the deubiquitinating activity of CYLD is correlated with tumorigenesis. It has been reported that expression of CYLD is detectable in brain, testis, skeletal muscle, spleen, liver, heart, lung and leukocytes (5). We have also demonstrated previously (21) that the human salivary gland tumor cell line, HSG, spontaneously expresses CYLD mRNA and protein.

Adenoid cystic carcinoma (ACC) is well known as a typical malignant salivary gland tumor. Facial palsy caused by perineural invasion of ACCs is particularly frequent. ACC 
was previously referred to as cylindroma because of its remarkable histologic resemblance to dermal cylindroma. We further found that ACC arising from the hard palate was distinctly positive for CYLD and NF- $\mathrm{KB}$-related factors, immunohistochemically (21). However, it is unclear whether loss of CYLD is associated with development of salivary gland tumors.

The present study was conducted to examine the function of CYLD in HSG cells. The expression and distribution of CYLD and NF- $\mathrm{KB}$-related factors were also investigated in 17 cases of ACC, to elucidate whether CYLD is associated with development of salivary gland tumors.

\section{Materials and methods}

Reagents. Rabbit anti-human CYLD polyclonal antibody (PAb CYLD), mouse anti-human RelA monoclonal antibody (MAb RelA), rabbit anti-human IкB $\alpha$ polyclonal antibody $(\mathrm{PAb}$ I $\mathrm{B} \alpha$ ), mouse anti-human IKK $\alpha$ monoclonal antibody (MAb IKK $\alpha$ ) and goat anti-human IKKß polyclonal antibody (PAb IKKß) were purchased from Santa Cruz Biotechnology (CA, USA).

Cell culture. The HSG cells established by Shirasuna et al (22) were maintained in RPMI-1640 medium supplemented with $10 \%$ heat-inactivated fetal bovine serum (FBS), $100 \mathrm{IU} /$ $\mathrm{ml}$ penicillin and $100 \mu \mathrm{g} / \mathrm{ml}$ streptomycin, and grown to confluence in $25-\mathrm{cm}^{2}$ culture flasks at $37^{\circ} \mathrm{C}$ in a humidified $5 \% \mathrm{CO}_{2}$ incubator until use.

$R N A$ extraction and RT-PCR. Total-RNA was extracted from the HSG cells using the acid-guanidinium-phenol-chloroform (AGPC) method reported previously (21). Random hexamerprimed single-stranded cDNA was synthesized with an RNA LA PCR ${ }^{\mathrm{TM}}$ Kit (Takara Shuzo, Shiga, Japan) from $1.0 \mu \mathrm{g}$ of total-RNA in a final volume of $20 \mu 1$ with 0.25 units of avian myeloblastosis virus reverse transcriptase at $42^{\circ} \mathrm{C}$ for $60 \mathrm{~min}$. An aliquot $(1.0 \mu \mathrm{l})$ of the reaction mixture was diluted with $10 \mu 1$ of PCR buffer containing 4 pmole each of $5^{\prime}$ and $3^{\prime}$ CYLD, NF- $\mathrm{BB}$ and $\mathrm{B}$-actin primer sets. The forward and reverse sequences of the oligonucleotides were as follows: CYLD forward primer, 5'-TCG CTG GAC TGG AAC TGG AAG-3'; reverse primer, 5'-GGA TGA AGG TGG ACT TGA GTG TTG-3'; NF-кB forward primer, 5'-CAC TTA TGG ACA ACT ATG AGG TCT CTG G-3'; reverse primer, 5'-CTG TCT TGT GGA CAA CGC AGT GGA ATT TTA GG-3'; B-actin forward primer, 5'-GTG GGG CGC CCC AGG CAC CA-3'; reverse primer, 5'-CTC CTT AAT GTC ACG CAC GAT TTC-3'. The PCR reaction was then performed with 2.5 units of Takara LA Taq ${ }^{\mathrm{TM}}$ (Takara). The samples were subjected to denaturation at $94^{\circ} \mathrm{C}$ for $2 \mathrm{~min}$. This was followed by 35 cycles of denaturation at $94^{\circ} \mathrm{C}$ for $30 \mathrm{sec}$, annealing at $56^{\circ} \mathrm{C}$ for CYLD mRNA and $65^{\circ} \mathrm{C}$ for NF- $\mathrm{BB}$ mRNA detections for $1 \mathrm{~min}$ each other, and extension at $72^{\circ} \mathrm{C}$ for $1 \mathrm{~min}$. For the last cycle, had the extension period was $10 \mathrm{~min}$. The amplified DNA was electrophoresed on a $2.0 \%$ agarose gel, stained with ethidium bromide and visualized on a UV illuminator, then photographed.

Protein extraction. To examine RelA translocation to the nucleus and the expression kinetics of CYLD, we used a subcellular proteome extraction kit (S-PEK) (Calbiochem, Darmstadt, Germany) in accordance with the manufacturer's instructions to extract the cytoplasm, membrane and nucleus fractions of HSG cells. Cells were treated with $10 \mathrm{ng} / \mathrm{ml}$ TNF- $\alpha$ for various periods $(0,15,30$ and $60 \mathrm{~min})$, pelleted $\left(5 \times 10^{6}\right.$ cells $)$, washed twice, resuspended in $1 \mathrm{ml}$ of ice-cold Extraction I containing $5 \mu \mathrm{l}$ of protease inhibitor mixture, and then incubated for $10 \mathrm{~min}$ at $4^{\circ} \mathrm{C}$ with gentle agitation. The suspension was centrifuged at $1000 \mathrm{x}$ g at $4^{\circ} \mathrm{C}$ for $10 \mathrm{~min}$, and the supernatant was used as the cytoplasm fraction; the pellet was resuspended in $1 \mathrm{ml}$ of ice-cold Extraction II containing $5 \mu \mathrm{l}$ of protease inhibitor mixture and incubated for $30 \mathrm{~min}$ at $4^{\circ} \mathrm{C}$. It was then centrifuged at $6000 \mathrm{x} \mathrm{g}$ at $4^{\circ} \mathrm{C}$ for $10 \mathrm{~min}$, and the supernatant used as the membrane fraction; the pellet was resuspended in $500 \mu 1$ of ice-cold Extraction III containing $5 \mu \mathrm{l}$ of protease inhibitor mixture and $1.5 \mu \mathrm{l}$ of Benzonase ${ }^{\circledR}$ and incubated for $10 \mathrm{~min}$ at $4^{\circ} \mathrm{C}$ with gentle agitation. It was then centrifuged at $7000 \mathrm{x} \mathrm{g}$ at $4^{\circ} \mathrm{C}$ for $10 \mathrm{~min}$, and the supernatant was used as the nucleus fraction. Protein concentrations were measured by Bio-Rad protein assay. Each supernatant fraction was subjected to immunoblot analysis.

Immunoblot analysis. For the detection of RelA and CYLD protein by gel electrophoresis, $30-\mu \mathrm{g}$ protein samples were mixed with an equal volume of SDS-PAGE sample buffer and boiled for $5 \mathrm{~min}$. The samples were then loaded and separated on polyacrylamide gel of appropriate percentage, and the proteins were electroblotted onto nitrocellulose membranes. Immunoblot analysis was carried out with each antibody according to the method described previously (21).

Transfection of HSG cells with plasmids and luciferase reporter assay. HSG cells $\left(1 \times 10^{5}\right.$ cells $\left./ \mathrm{ml}\right)$ were cultured for $12 \mathrm{~h}$ in 24-well culture plates containing RPMI-1640 supplemented with $10 \%$ FBS. pTKкB2luc, the thymidine kinase (TK) luciferase construct containing five copies of the $\mathrm{\kappa B}$ motif from the CXCL10/IP-10 gene, has been described earlier (23). Cells were transiently transfected with pTKкB2luc and pRL-TK reference Renilla luciferase plasmid (Promega, Madison, WI, USA) by using FuGene transfection reagents (Roche, Nutley, NJ, USA), in accordance with the manufacturer's instructions. Twenty-four hours after transfection, the cells were treated with TNF- $\alpha$ for various periods $(0,1,4$, 8 and 24 h). Firefly and Renilla luciferase activities were assayed using reagents provided by Promega, in accordance with the instructions supplied. For standardization of transfection efficiency, the luciferase activity from pTKкB2luc was normalized to the Renilla luciferase activity. The pGL3 control luciferase plasmid was purchased from Promega.

RNA-mediated interference. Small interfering RNAs (siRNAs) specific for human CYLD and scrambled (control) were synthesized by Sigma-Aldrich, Inc. (Ishikari, Japan). The sense and antisense strand sequences of the oligonucleotides were as follows: CYLD siRNA sense, CAG AUU GAG CGC UGU AAC UCU; antisense, AGU UAC AGC GCU CAA UCU GAU; control siRNA sense, UUC GAC GUA AUC GGG UCU ACA; antisense, UAG ACC CGA UUA 
CGU CGA AUU. FuGene 6 transfection reagent was mixed with $10 \mu \mathrm{M}$ CYLD or $10 \mu \mathrm{M}$ control siRNA $(3: 3.4 \mu 1)$ in serum-free medium, to a total volume of $100 \mu \mathrm{l}$ and incubated for $30 \mathrm{~min}$ at room temperature. For siRNA delivery, HSG cells $\left(1 \times 10^{5}\right.$ cells $\left./ \mathrm{ml}\right)$ were rinsed with serumfree medium and transfected in 24-well plates with an NF$\kappa \mathrm{B}$-dependent luciferase reporter plasmid and either a CYLD siRNA duplex or a control siRNA using FuGene 6 transfection reagents for $48 \mathrm{~h}$ at $37^{\circ} \mathrm{C}$. Cells were treated with TNF- $\alpha$ for $4 \mathrm{~h}$, and subjected to luciferase reporter assay and immunoblot analysis.

Primary tumor samples. Formalin-fixed, paraffin-embedded specimens were obtained by surgical biopsy from 17 patients with ACC treated at Meikai University Hospital, Japan. The pathological diagnosis of oral lesions was based on histological examination of hematoxylin and eosin-stained slides and made according to the WHO classification (24). The TNM stage was determined according to the TNM pathological classification of the UICC (International Union Against Cancer) (25). None of the patients had undergone preoperative chemotherapy or radiotherapy. The labeling index was defined as the percentage of tumor cells displaying immunoreactivity, and calculated by counting the number of CYLD and NF-кBrelated factor-positive tumor cells among 1,000 tumor cells in each section. Tissue sections with $<5 \%$ reactive cells were defined as negative (-), and those with $\geq 5 \%$ positive reactive cells were defined as positive $(+)$.

Immunostaining of adenoid cystic carcinomas. The sections were immersed in absolute methanol containing $0.3 \% \quad \mathrm{H}_{2} \mathrm{O}_{2}$ for $20 \mathrm{~min}$ at room temperature to block endogenous peroxidase activity. Immunohistochemistry was carried out with each antibody according to the method reported previously (21).

Ethical considerations. The study was approved by the Research Ethics Committee of Meikai University School of Dentistry, Saitama, Japan.

\section{Results}

Detection of CYLD and RelA mRNAs in HSG cells stimulated with TNF- $\alpha$. To examine how expression of CYLD and RelA mRNA is regulated in HSG cells upon stimulation with TNF- $\alpha$, semi-quantitative RT-PCR was carried out. This showed that the expression of both CYLD and RelA mRNA was increased in HSG cells stimulated with $\mathrm{TNF}-\alpha$, in comparison with non-stimulated HSG cells (Fig. 1).

Correlation between expression of CYLD and RelA protein in HSG cells. To examine how the expression of RelA and CYLD protein is regulated in HSG cells upon stimulation with TNF- $\alpha$, immunoblot analysis was carried out. The immunoblot data were also evaluated by densitometric analysis. Translocation of RelA from the cytoplasm to the nucleus in HSG cells was reached a peak at $30 \mathrm{~min}$, then decreased at $60 \mathrm{~min}$ (Fig. 2A and $\mathrm{B}$, left). When the time course of RelA protein expression was analyzed up to $24 \mathrm{~h}$, nuclear translocation of RelA was

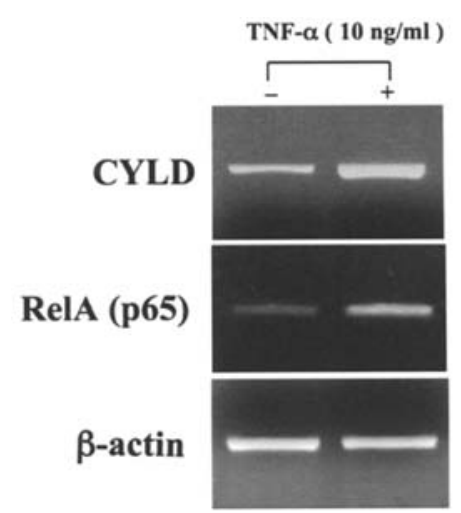

Figure 1. Semi-quantitative RT-PCR. The mRNA expressions of both CYLD and RelA were increased in HSG cells stimulated with $10 \mathrm{ng} / \mathrm{ml}$ TNF- $\alpha$ for $24 \mathrm{~h}$, in comparison with non-stimulated HSG cells. As an internal control, B-actin mRNA detection revealed that the total-RNA obtained was intact.

further decreased (data not shown). CYLD was localized mainly in the cell membrane, and its intensity in HSG cells after treatment with $\mathrm{TNF}-\alpha$ increased gradually with time during $60 \mathrm{~min}$ (Fig. 2A and B, right). Thereafter, expression of CYLD protein decreased gradually up to $24 \mathrm{~h}$ (data not shown).

$N F-\kappa B$ activation in $H S G$ cells stimulated with TNF- $\alpha$. To investigate the effect of TNF- $\alpha$ on NF-кB-dependent transcriptional activity in $\mathrm{HSG}$ cells, luciferase reporter assay was carried out. TNF- $\alpha$ caused strong induction of luciferase activity (Fig. 3). Maximum $\kappa$ B-dependent transcription was observed at $4 \mathrm{~h}$, and this induced a 5-fold increase in luciferase activity compared with cells not exposed to TNF- $\alpha$. This did not increase further with time. However, constitutive NF-кB activity was not observed in HSG cells. The increase in luciferase activity was completely dependent on the presence of $\kappa \mathrm{B}$ sites, since the control plasmid lacking the $\mathrm{\kappa B}$ elements did not respond to TNF- $\alpha$.

$C Y L D$ is a negative regulator of $N F-\kappa B$ activation in $H S G$ cells. To determine whether endogenous CYLD indeed functions as a negative regulator of $N F-\kappa B$ activation by TNF- $\alpha$ in HSG cells, we used a siRNA approach to reduce the expression of CYLD and determined the effects on the basal and TNF- $\alpha$-induced activity of NF- $\kappa \mathrm{B}$. As expected, the CYLD protein was markedly reduced by CYLD siRNA (Fig. 4A). We then assessed the effect of CYLD siRNA on NF- $\kappa$ B-dependent transcriptional activity by TNF- $\alpha$ for $4 \mathrm{~h}$. As shown in Fig. 4B, CYLD knockdown by CYLD siRNA greatly enhanced NF- $\kappa \mathrm{B}$ activation by TNF- $\alpha$ in HSG cells, in comparison with transfection using CYLD scrambled siRNA. These data suggested that CYLD functions as a negative regulator of NF- $\kappa \mathrm{B}$ activation induced by TNF- $\alpha$ in HSG cells.

Immunohistochemical detection of CYLD and $N F-\kappa B$-related factors and clinicopathological variables in ACC tissues. The correlations between expression of CYLD and NF-кBrelated factors and clinicopathological variables in ACC tissues 


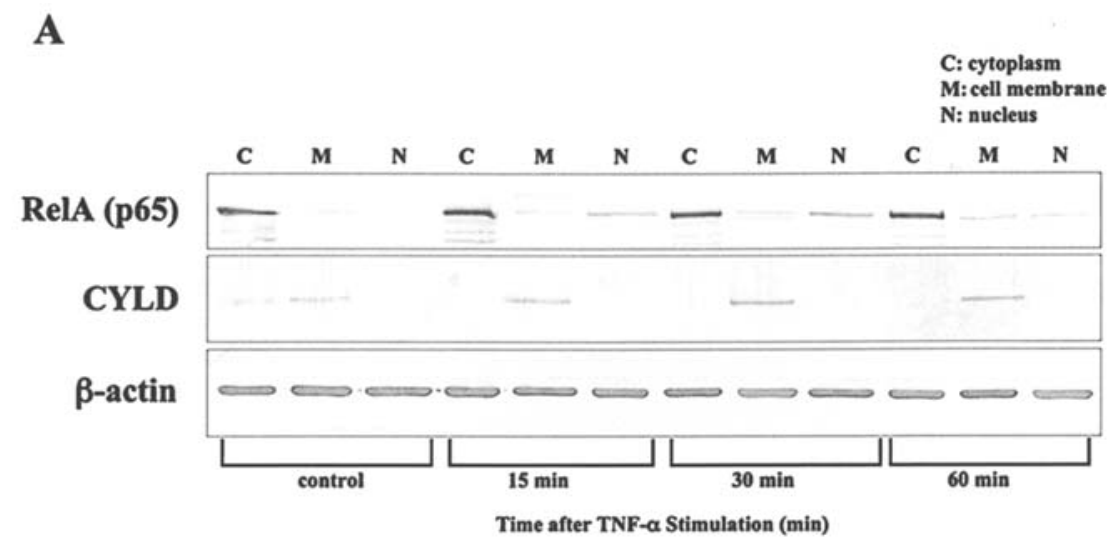

B
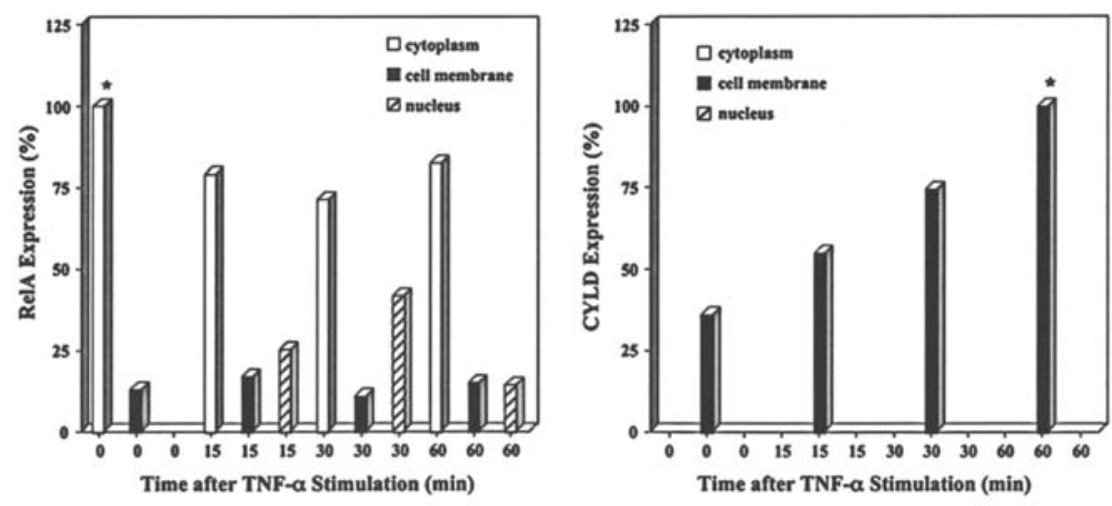

Figure 2. Immunoblot analysis. (A) Measurable translocation of RelA from the cytoplasm to the nucleus in HSG cells was clearly observed at 30 min, then decreased at $60 \mathrm{~min}$. CYLD was mainly localized in the cell membrane and the intensity in HSG cells after treatment with $10 \mathrm{ng} / \mathrm{ml} \mathrm{TNF}-\alpha$ gradually increased with time during $60 \mathrm{~min}$. (B) The data were also evaluated by densitometric analysis. Filters were scanned and computer-generated images were analyzed with the National Institutes of Health IMAGE program to obtain densitometric values. For each series of samples (cytoplasm, cell membrane and nucleus), the relative density of each image was calculated and expressed as a percentage of the value (arbitrarily set at 100) indicated by an asterisk.

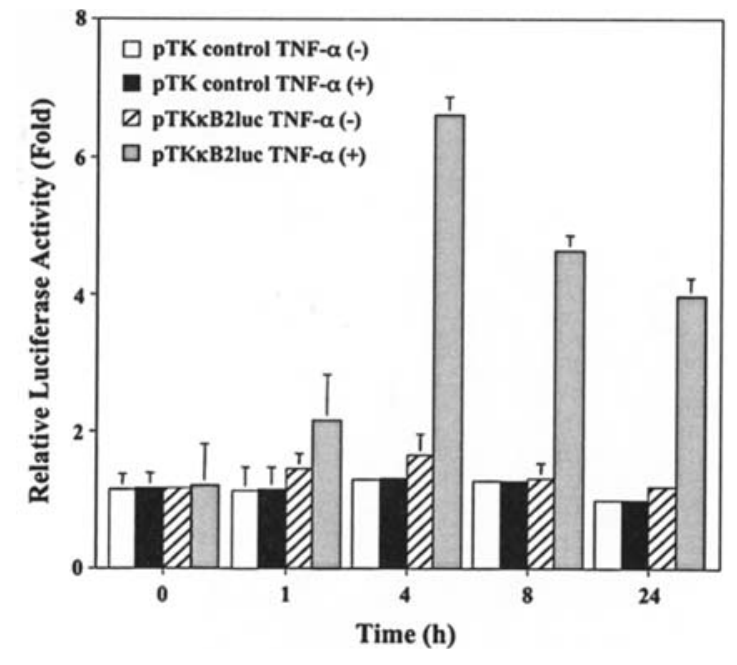

Figure 3. Luciferase reporter assay. Maximal $\kappa \mathrm{B}$-dependent transcription was observed with $10 \mathrm{ng} / \mathrm{ml} \mathrm{TNF-} \alpha$ at $4 \mathrm{~h}$. This induced a 5-fold increase in luciferase activity compared with cells not exposed to TNF- $\alpha$, which showed no further increase with time. Constitutive NF-кB activity was not observed in HSG cells. The increase in luciferase activity was completely dependent on the presence of $\kappa \mathrm{B}$ sites, since the control plasmid lacking the $\kappa \mathrm{B}$ elements showed no response to TNF- $\alpha$. The relative luciferase activities are shown as -fold induction compared with the activity of untreated control samples at $24 \mathrm{~h}$. Each column and bar represents the mean \pm SEM of three independent experiments. are summarized in Table I. Immunohistochemistry was carried out in a total of 17 cases of ACC at various stages. Histologically, all the cases of ACC analyzed in this study were cribriform. Immunohistochemistry showed that CYLD and NF-KB-related factors were present sporadically and/or in aggregates in the cribriform and duct-like structure of ACC tissues. Positive reactivity with PAb CYLD was clearly observed on the membrane and in the cytoplasm of cancer cells in 10 of 17 cases (58.8\%) of ACC (Fig. 5A), whereas positive reactivity with MAb RelA was observed in the cytoplasm in 12 cases (70.6\%) (Fig. 5B). Positive reactivity with PAb IкB $\alpha$ was observed in the nucleus in 13 cases $(76.5 \%)$ (Fig. 5C). There was an inverse relationship between the expression of CYLD and that of RelA. Conversely, there was a positive relationship between RelA and IкB $\alpha$. Positive reactivity with MAb IKK $\alpha$ was strongly observed in the cytoplasm of cancer cells in 14 cases (82.4\%) (Fig. 5D), and positive reactivity with $\mathrm{PAb}$ IKKß was weakly observed in the cytoplasm in 4 cases (23.5\%) (Fig. 5E). These results indicated that IKK $\alpha$ is expressed more dominantly than IKK $\beta$ in ACC tissues. However, no significant association was found between expression of CYLD or NF-KB-related factor and clinicopathological variables (age, gender, location, TNM and stage). 
A

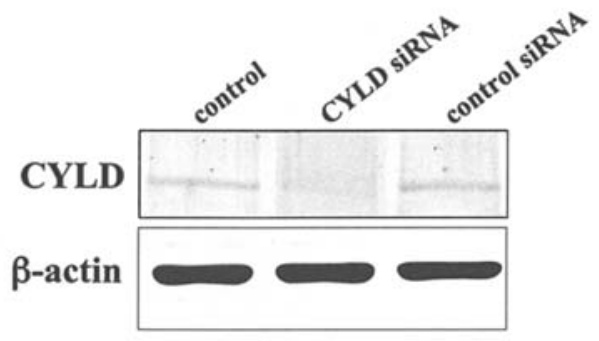

B

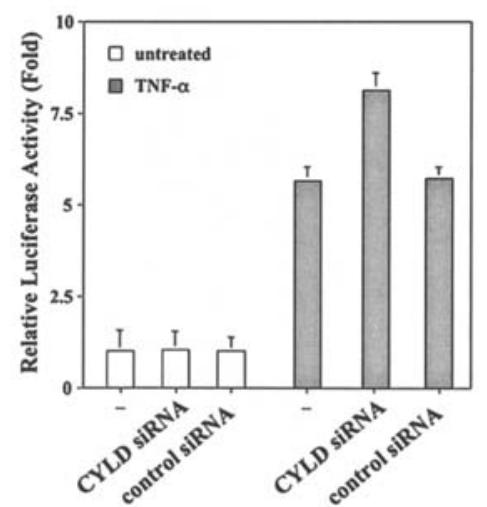

Figure 4. CYLD siRNA-mediated interference. (A) Endogenous CYLD protein was markedly reduced by CYLD siRNA. (B) CYLD siRNA greatly enhanced activation of NF- $\kappa$ B by TNF- $\alpha$ in HSG cells, in comparison with CYLD scrambled siRNA transfection. The relative luciferase activities are shown as -fold induction compared with the activity of untreated samples. Each column and bar represents the mean \pm SEM of three independent experiments.

\section{Discussion}

In the present study, we investigated how the expression of CYLD and NF- $\mathrm{NB}$ mRNA is regulated in salivary gland tumor cells upon stimulation with $\mathrm{TNF}-\alpha$. It was found that the levels of CYLD and NF- $\kappa \mathrm{B}$ mRNAs expression were clearly increased in HSG cells during $24 \mathrm{~h}$ after treatment with TNF- $\alpha$. We also found that translocation of NF- $\kappa \mathrm{B}$ from the cytoplasm to the nucleus in HSG cells peaked as early as 30 min after treatment with TNF- $\alpha$, then decreased at $60 \mathrm{~min}$, whereas CYLD protein on the HSG cell membrane gradually increased with time during $60 \mathrm{~min}$. Furthermore, luciferase reporter assay indicated that TNF- $\alpha$ induced a 5-fold increase of $\mathrm{NF}-\kappa \mathrm{B}$ at $4 \mathrm{~h}$ compared with cells not exposed to TNF- $\alpha$, and that thereafter the NF- $\mathrm{KB}$ activity decreased gradually, although constitutive NF- $\mathrm{KB}$ activity was not observed in HSG cells. Taken together, these data suggest that the levels of both CYLD and NF- $\kappa$ B mRNAs accumulated in HSG cells during $24 \mathrm{~h}$ after TNF- $\alpha$ stimulation, although the NF- $\kappa \mathrm{B}$ activity in the cells was at least negatively regulated by CYLD. To clarify this possibility, CYLD knockdown analysis was carried out using siRNA, and this showed that NF- $\mathrm{BB}$ activation was greatly enhanced at $4 \mathrm{~h}$ after $\mathrm{TNF}-\alpha$ stimulation in HSG cells. These results were consistent with a previous report (9), and suggested that although CYLD negatively regulates NF- $\mathrm{KB}$ activation induced by TNF- $\alpha$ in HSG cells, it has no effect on constitutive $\mathrm{NF}-\kappa \mathrm{B}$ activity. Constitutive $\mathrm{NF}-\kappa \mathrm{B}$ activity is present in many tumor cells and is associated with the induction of genes involved in cell survival and also in tumor progression and metastasis $(11,26-28)$. However, more recent studies have also indicated that inhibition of $\mathrm{NF}-\kappa \mathrm{B}$ activity leads to cell proliferation and development of

Table I. Correlation between the expression of NF-кB, IкB $\alpha$, CYLD, IKK $\alpha$, IKKß and clinicopathological variables in adenoid cystic carcinomas.

\begin{tabular}{|c|c|c|c|c|c|c|c|c|c|c|}
\hline No. & Age & Gender & Location & TNM & Stage & CYLD & $\mathrm{NF}-\kappa \mathrm{B}$ & $\mathrm{I} \kappa \mathrm{B} \alpha$ & $\operatorname{IKK} \alpha$ & IKK $\beta$ \\
\hline 1 & 58 & $\mathrm{~F}$ & Oral floor & T1N0M0 & $\mathrm{I}$ & + & - & + & + & - \\
\hline 2 & 62 & $\mathrm{~F}$ & Sinus & $\mathrm{T} 2 \mathrm{~N} 1 \mathrm{M} 0$ & III & + & - & - & + & - \\
\hline 3 & 50 & $\mathrm{~F}$ & Submandibular gland & T2N0M0 & II & + & - & - & + & - \\
\hline 4 & 31 & $\mathrm{~F}$ & Submandibular gland & T3N1M0 & IVA & + & - & - & + & - \\
\hline 5 & 73 & $\mathrm{~F}$ & Oral floor & T2N0M0 & II & + & - & - & + & - \\
\hline 6 & 64 & M & Oral floor & T2N0M0 & II & + & ++ & +++ & +++ & \\
\hline 7 & 58 & $\mathrm{~F}$ & Oral floor & T3N0M0 & III & + & ++ & + & ++ & - \\
\hline 8 & 44 & $\mathrm{~F}$ & Submandibular gland & T3N0M0 & III & + & ++ & +++ & + & + \\
\hline 9 & 57 & M & Hard palate & T1N0M0 & I & + & ++ & + & ++ & + \\
\hline 10 & 46 & $\mathrm{M}$ & Oral floor & T2NOM0 & II & ++ & + & + & + & - \\
\hline 11 & 59 & $\mathrm{~F}$ & Nasal cavity & T2NOM0 & II & - & ++ & ++ & ++ & - \\
\hline 12 & 27 & $\mathrm{~F}$ & Hard palate & $\mathrm{T} 2 \mathrm{~N} 1 \mathrm{M} 0$ & III & - & + & + & + & + \\
\hline 13 & 66 & $\mathrm{~F}$ & Oral floor & T4N3M0 & IVB & - & + & + & - & - \\
\hline 14 & 70 & $\mathrm{~F}$ & Oral floor & T2N0M0 & II & - & + & + & - & - \\
\hline 15 & 58 & $\mathrm{~F}$ & Hard palate & T4N1M0 & IVA & - & + & + & - & - \\
\hline 16 & 52 & M & Submandibular gland & T1N0M0 & I & - & ++ & +++ & + & + \\
\hline 17 & 81 & $\mathrm{M}$ & Buccal mucosa & T1N0M0 & I & - & + & ++ & + & - \\
\hline
\end{tabular}



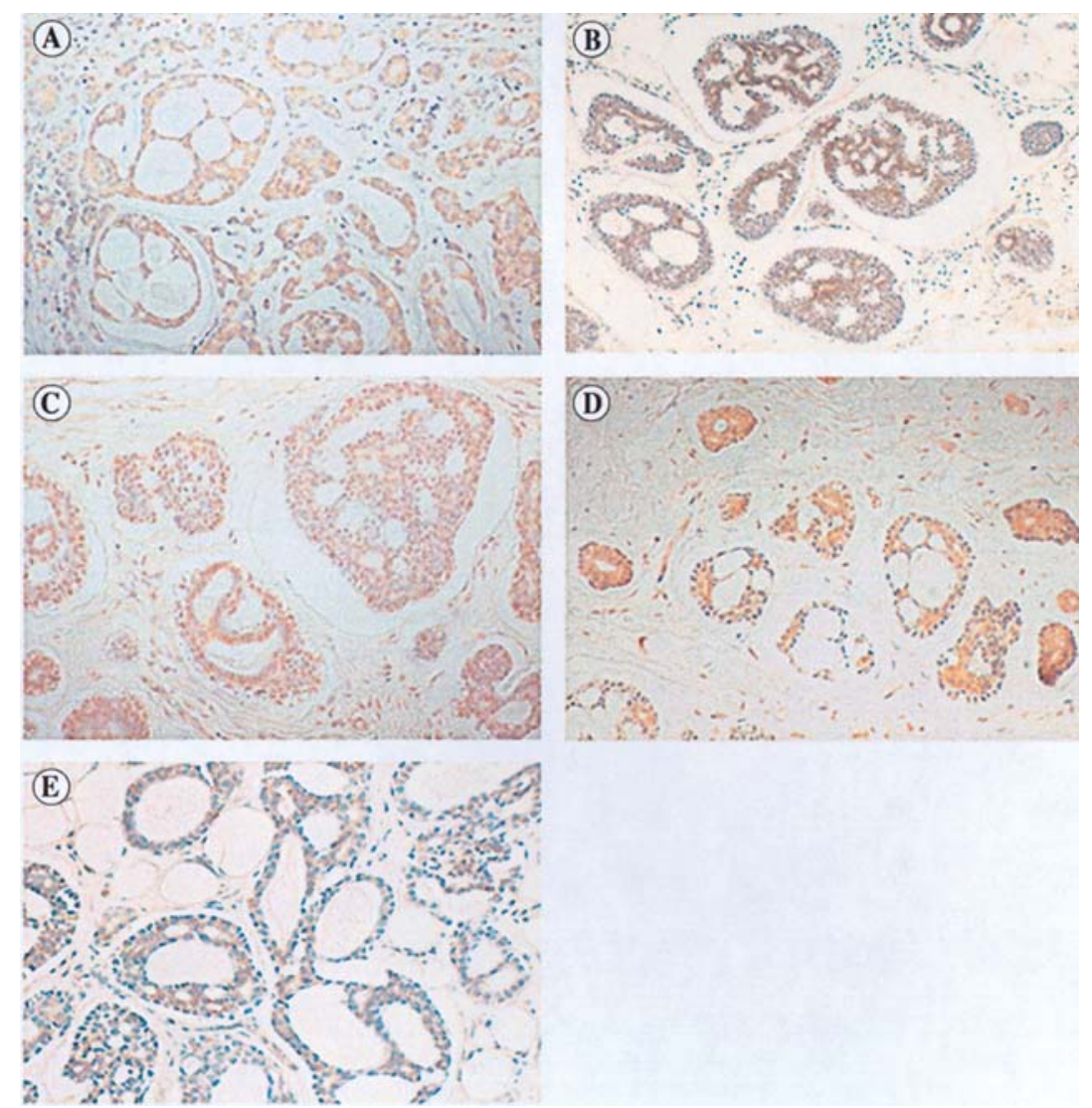

Figure 5. Immunohistochemistry. Immunoreactivity of CYLD and NF-kB-related factors were found sporadically and/or in aggregates in the cribriform and duct-like structure of ACC tissue. (A) A positive reaction with PAb CYLD was clearly observed in the membrane and cytoplasm of cancer cells (x66). (B) A positive reaction with MAb RelA was observed in the cytoplasm of cancer cells (x66). (C) A positive reaction with PAb IkB $\alpha$ was observed in the nucleus of cancer cells (x66). (D) A strongly positive reaction with MAb IKK $\alpha$ was observed in the cytoplasm of cancer cells (x66). (E) A weakly positive reaction with PAb IKKß was observed in the cytoplasm of cancer cells (x66).

squamous cell carcinoma (29). Furthermore, some types of tumor cells such as colon cancer cells show a decreased level of NF- $\mathrm{KB}$ activity (30). These lines of study, together with the results presented herein, suggest that down-regulation of $\mathrm{NF}-\kappa \mathrm{B}$ activity might be involved in tumorigenesis in certain types of cancer cells via increased cell proliferative activity.

On the other hand, although ACCs are not so aggressive biologically, they can give rise to metastases many years after excision of the primary tumor. Furthermore, the frequency of CYLD expression in ACC is largely unknown. In this study, therefore, the frequency of CYLD expression, together with expression of $\mathrm{NF}-\kappa \mathrm{B}$-related factors, was investigated in 17 cases of ACC. No correlations were detected between clinicopathological variables and expression of CYLD or NF- $\mathrm{KB}$-related factors. However, expression of CYLD was negatively correlated with that of RelA, i.e., RelA tended to be absent in cases expressing CYLD. These results imply that $N F-\kappa B$ activation is inhibited in cases with normal CYLD function, whereas inversely it tends to be overexpressed in cases where CYLD is not functional. Hence, these findings suggest that CYLD may be dysfunctional in ACC cases where CYLD is not detectable, or that NF- $\mathrm{KB}$ is activated despite the expression of CYLD. Twelve of 17 ACC cases (70.6\%) were suspected to have CYLD dysfunction, thus indicating that CYLD might be a useful marker of tumor development and prognosis in
ACC. This observation also suggests that CYLD mutation is significantly associated with ACC tumorigenesis, and that there is a substantial need for analysis of CYLD gene alterations in ACC. Furthermore, there was a positive correlation between the expression of RelA and that of IкB $\alpha$, i.e., RelApositive cases were mostly positive for IкB $\alpha$. Whereas RelA that was efficiently expressed in 12 of the 17 ACC cases $(70.6 \%)$ was observed in the cytoplasm of most tumor cells, $\mathrm{I} \kappa \mathrm{B} \alpha$ was detected in the nucleus. Although the IкB proteins were first identified as cytoplasmic inhibitors of $\mathrm{NF}-\kappa \mathrm{B}$ proteins, it is now clear that IкB proteins also act in the nucleus (31). In addition, the finding that IKK $\alpha$ expression was stronger than IKK $\beta$ expression suggests that IKK $\alpha$ may have a dominant role in comparison to IKKß in ACC tissues, although targeted gene disruptions have demonstrated that IKK $\beta$ (but not IKK $\alpha$ ) is largely responsible for cytokineinduced I $\mathrm{B}$ degradation, the NF- $\kappa \mathrm{B}$ activation pathway and suppression of apoptosis (32-34). In light of the present findings, these phenomena are quite difficult to understand, because NF- $\mathrm{NB}$ is generally activated by $\mathrm{I} \kappa \mathrm{B} \alpha$ phosphorylation. Conversely, down-regulation of $\mathrm{I} \kappa \mathrm{B} \alpha$ phosphorylation prevents $\mathrm{NF}-\kappa \mathrm{B}$ translocation to the nucleus, and the expression of NF-кB-responsive genes is thereby arrested. As a consequence, these phenomena may promote ACC cell apoptosis. However, ACC never regresses as a result of autonomic apoptosis, but instead progresses slowly. This 
implies that ACC is not so aggressive, although it does have a potential for high malignancy. Although we cannot account for these results, it has been demonstrated that $\mathrm{I}_{\kappa} \mathrm{B} \alpha$ regenerates the cytoplasmic pool of $\mathrm{NF}-\kappa \mathrm{B}$ in preparation for subsequent reactivation (31). It has also been suggested that

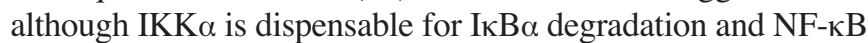
nuclear translocation, it may be required in the PI3K/AKT pathway that leads to the phosphorylation of $\mathrm{I} \kappa \mathrm{B} \alpha$ and activation of NF- $\mathrm{BB}(34)$. From these combined data, and the fact that expression of IKK $B$ in ACC tissues was hardly detectable, it is speculated that an unknown event in the progression mechanisms of ACC exists. In this regard, determining the signaling pathway occurring in these events might be the key to elucidating the mechanism of development of adenoid cystic carcinomas.

Based on these in vitro and in vivo observations, one can hypothesize that loss of CYLD function leads to NF-kB activation and subsequently anti-apoptosis, and that as a consequence, it might be associated with tumorigenesis, including growth, development and perineural invasion in human salivary gland tumors, such as ACC.

Further investigation of the role of CYLD, including its interaction with NF- $\mathrm{BB}$-related factors and analysis of CYLD gene alterations in salivary gland tumor cells, will be required to establish a strategy for CYLD-based therapy of salivary gland tumors.

\section{Acknowledgements}

This study was supported by a Grant-in-Aid for scientific research from the Ministry of Education, Science and Culture of Japan.

\section{References}

1. Lever W and Schaumburg-Lever G: Histopathology of the skin. 7th edition. Lippincott, JB, Philadelphia, pp848-851, 1990.

2. Tellechea O, Reis JP, Ilheu O and Baptista AP: Dermal cylindroma. An immunohistochemical study of thirteen cases. Am J Dermatopathol 17: 260-265, 1995.

3. Biggs PJ, Wooster R, Ford D, et al: Familial cylindromatosis (turban tumour syndrome) gene localised to chromosome 16q12-q13: evidence for its role as a tumour suppressor gene. Nat Genet 11: 441-443, 1995.

4. Biggs PJ, Chapman P, Lakhani SR, Burn J and Stratton MR: The cylindromatosis gene (cyld1) on chromosome $16 \mathrm{q}$ may be the only tumour suppressor gene involved in the development of cylindromas. Oncogene 12: 1375-1377, 1996.

5. Bignell GR, Warren W, Seal S, et al: Identification of the familial cylindromatosis tumour-suppressor gene. Nat Genet 25: 160-165, 2000.

6. Takahashi M, Rapley E, Biggs PJ, et al: Linkage and LOH studies in 19 cylindromatosis families show no evidence of genetic heterogeneity and refine the CYLD locus on chromosome 16q12-q13. Hum Genet 106: 58-65, 2000.

7. Brummelkamp TR, Nijman SM, Dirac AM and Bernards R: Loss of the cylindromatosis tumour suppressor inhibits apoptosis by activating NF-kappaB. Nature 424: 797-801, 2003.

8. Kovalenko A, Chable-Bessia C, Cantarella G, Israel A, Wallach D and Courtois G: The tumour suppressor CYLD negatively regulates NF-kappaB signalling by deubiquitination. Nature 424: 801-805, 2003.

9. Trompouki E, Hatzivassiliou E, Tsichritzis T, Farmer H, Ashworth A and Mosialos G: CYLD is a deubiquitinating enzyme that negatively regulates NF-kappaB activation by TNFR family members. Nature 424: 793-796, 2003.
10. Li Q and Verma IM: NF-kappaB regulation in the immune system. Nat Rev Immunol 2: 725-734, 2002.

11. Karin M, Cao Y, Greten FR and Li ZW: NF-кB in cancer: from innocent bystander to major culprit. Nat Rev Cancer 2: 301-310, 2002.

12. Orlowski RZ and Baldwin AS Jr: NF-kappaB as a therapeutic target in cancer. Trends Mol Med 8: 385-389, 2002.

13. Baeuerle PA and Baltimore D: I kappa B: a specific inhibitor of the NF-kappa B transcription factor. Science 242: 540-546, 1988

14. Baeuerle PA and Baltimore D: A 65-kappaD subunit of active NF-kappaB is required for inhibition of NF-kappaB by I kappaB. Genes Dev 3: 1689-1698, 1989.

15. Haskill S, Beg AA, Tompkins SM, et al: Characterization of an immediate-early gene induced in adherent monocytes that encodes I kappa B-like activity. Cell 65: 1281-1289, 1991.

16. Karin M: The beginning of the end: IkappaB kinase (IKK) and NF-kappaB activation. J Biol Chem 274: 27339-27342, 1999.

17. Mercurio $\mathrm{F}$, Zhu H, Murray BW, et al: IKK-1 and IKK-2: cytokine-activated IkappaB kinases essential for NF-kappaB activation. Science 278: 860-866, 1997.

18. May MJ and Ghosh S: IkappaB kinases: kinsmen with different crafts. Science 284: 271-273, 1999.

19. Karin M: How NF-кB is activated: the role of the IкB kinase (IKK) complex. Oncogene 18: 6867-6874, 1999.

20. Smahi A, Courtois G, Rabia SH, et al: The NF-kappaB signalling pathway in human diseases: from incontinentia pigmenti to ectodermal dysplasias and immune-deficiency syndromes. Hum Mol Genet 11: 2371-2375, 2002.

21. Fukuda M, Fukuda F, Horiuchi Y, Oku Y, Suzuki S, Kusama K and Sakashita H: Expression of CYLD, NF-kappaB and NFkappaB-related factors in salivary gland tumors. In Vivo 20: 467-472, 2006.

22. Shirasuna K, Sato M and Miyazaki T: A neoplastic epithelial duct cell line established from an irradiated human salivary gland. Cancer 48: 745-752, 1981.

23. Ohmori Y and Hamilton TA: Interleukin-4/STAT6 represses STAT1 and NF-kappa B-dependent transcription through distinct mechanisms. J Biol Chem 275: 38095-38103, 2000.

24. Seifert G (ed): Histological typing of salivary gland tumours. 2nd edition. World Health Organization International Histological Classification of Tumors, Springer-Verlag, Berlin, pp21-47, 1991.

25. Sobin LH and Wittekind CH (eds): UICC TNM classification of malignant tumors. 5th edition. John Wiley and Sons, Inc., New York, pp20-24, 2002.

26. Nakshatri H, Bhat-Nakshatri P, Martin DA, Goulet RJ Jr and Sledge GW Jr: Constitutive activation of NF-кB during progression of breast cancer to hormone-independent growth. Mol Cell Biol 17: 3629-3639, 1997.

27. Nakayama H, Ikebe T, Beppu M and Shirasuna K: High expression levels of nuclear factor $\kappa \mathrm{B}$, IкB kinase $\alpha$ and Akt kinase in squamous cell carcinoma of the oral cavity. Cancer 92: 3037-3044, 2001.

28. Rani MR, Asthagiri AR, Singh A, et al: A role for NF-кB in the induction of $\beta-R 1$ by interferon- $\beta$. J Biol Chem 276: 44365-44368, 2001

29. Dajee M, Lazarov M, Zhang JY, et al: NF-кB blockade and oncogenic Ras trigger invasive human epidermal neoplasia. Nature 421: 639-643, 2003

30. Deng J, Miller SA, Wang HY, et al: B-catenin interacts with and inhibits NF-кB in human colon and breast cancer. Cancer Cell 2: $323-334,2002$

31. Huang TT and Miyamoto S: Post-repression activation of NF-кB requires the amino-terminal nuclear export signal specific to IкB $\alpha$. Mol Cell Biol 21: 4737-4747, 2001.

32. Li Q, Estepa G, Memet S, Israel A and Verma IM: Complete lack of NF-kappaB activity in IKK1 and IKK2 double-deficient mice: additional defect in neurulation. Genes Dev 14: 1729-1733, 2000.

33. Li Q, Lu Q, Hwang JY, Buscher D, Lee KF, Izpisua-Belmonte JC and Verma IM: KK1-deficient mice exhibit abnormal development of skin and skeleton. Genes Dev 13: 1322-1328, 1999.

34. Sizemore N, Lerner N, Dombrowski N, Sakurai H and Stark GR: Distinct roles of the IкB kinase $\alpha$ and $\beta$ subunits in liberating nuclear factor $\kappa \mathrm{B}(\mathrm{NF}-\kappa \mathrm{B})$ from IкB and in phosphorylating the p65 subunit of NF-кB. J Biol Chem 277: 3863-3869, 2001. 